\title{
BUDIDAYA RAJUNGAN DALAM KERAMBA JARING DITENGGELAMKAN SECARA TERPADU DI PERAIRAN KECAMATAN SIGERI KABUPATEN PANGKEP
}

\section{(Rajungan cultivation management in the network of the integrated network damaged in the waters of Sigeri District, Pangkep District)}

\author{
Susan Yubelin De Fretes ${ }^{1)}$, Ihsan ${ }^{2)}$ dan Hasrun ${ }^{2)}$ \\ 1) Mahasiswa Program Studi PascaSarjana PPS UMI Makassar \\ 2) Program Studi Budidaya Perairan FIKP UMI Makassar \\ Koresponden:susandefretes@yahoo.com
}

Diterima tanggal: 2 Juli 2019; disetujui 2 Sepetember 2019

\begin{abstract}
This study aims to (1) examine the physical and chemical aspects of marine oceanography, (2) determine the suitability of location and swimming crab culture techniques in submerged net cages, (3) find out the management strategies of crab culture management in submerged net cages. The results showed that the suitability of waters for crab cultivation activities in the karamba nets was submerged by using indicators of temperature, salinity, oxygen, $p H$ and brightness obtained two suitability criteria, namely sesai and not. The results of the suitability analysis of crab cultivation land using a Geographic Information System (GIS) obtained two criteria for suitability of cultivated land with an area of each appropriate category that is 46,785.32 ha and not according to 1,152.4 ha. The results of management strategies that can be applied to realize integrated management of small crab culture include: 1) Development and socialization of small crab culture; 2) Management of integrated small crab cultivation; 3) Law enforcement related to the destruction of coastal ecosystems 4) Prohibition of capturing crabs laying eggs; 5) Construction of small crab hatcheries for small crab cultivation needs; 6) Development and provision of venture capital.
\end{abstract}

Keywords: Physical, Chemical Aspects, Marine Oceanography, Culture, Submerged Net Cages, Management Strategies

\begin{abstract}
ABSTRAK
Penelitian ini bertujuan untuk (1) mengkaji aspek fisika dan kimia oseanografi perairan, (2) mengetahui kesesuaian lokasi dan teknik budidaya rajungan dalam karamba jaring ditenggelamkan, (3) mengetahui strategi pengelolaan budidaya rajungan dalam karamba jaring ditenggelamkan. Hasil penelitian menunjukan kesesuaian perairan untuk kegiatan budidaya rajungan dalam karamba jaring ditenggelamkan dengan menggunakan indikator suhu, salinitas, oksigen, $\mathrm{pH}$ dan kecerahan diperoleh dua kriteria kesesuaian yaitu sesai dan tidak sesuai. Hasil analisis kesesuaian lahan budidaya rajungan menggunakan Sistem Informasi Geografis (SIG) diperoleh dua kriteria kesesuaian lahan budidaya dengan luas masing-masing kategori sesuai yaitu 46.785,32 ha dan tidak sesuai 1.152,4 ha. Hasil strategi pengelolaan yang dapat diterapkan untuk mewujudkan pengelolaan budidaya rajungan secara terpadu, antara lain : 1) Pengembangan dan sosialisasi budidaya rajungan; 2) Pengeloaan budidaya rajungan secara terpadu; 3) Penegakan hukum terkait perusakan ekosistem pesisir 4) Pelarangan penangkapan rajungan yang bertelur; 5) Pembangunan hatchery bibit rajungan untuk kebutuhan budidaya rajungan; 6) Pengembangan dan pemberian modal usaha.
\end{abstract}

Kata Kunci: Aspek Fisika, kimia Oseanografi, Perairan, Budidaya Rajungan, Strategi Pengelolaan. 


\section{PENDAHULUAN}

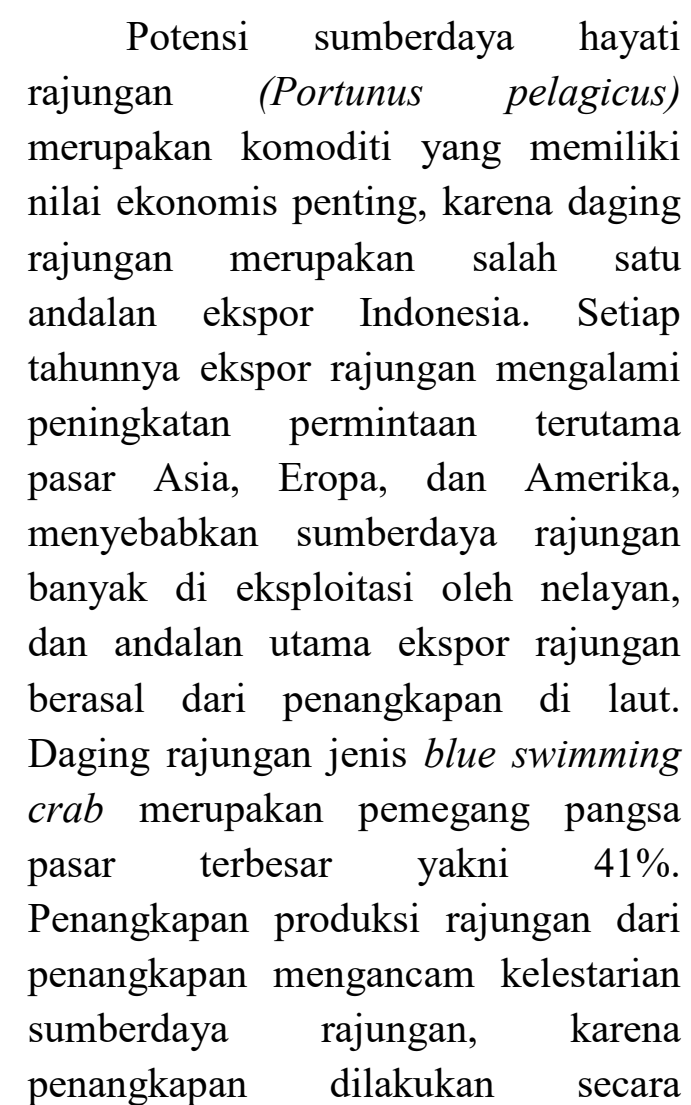
intensif. Perikanan, merupakan salah satu aktivitas yang memberikan kontribusi terhadap kesejahteraan suatu bangsa. Sebagai salah satu sumberdaya alam yang bersifat dapat diperbaharui (renewable), pengelolaan sumberdaya ini memerlukan pendekatan yang bersifat menyeluruh dan hati-hati (Fauzi dan Anna, 2004).

Perairan Pangkajene Kepulauan merupakan suatu lingkup perairan yang memiliki potensi perikanan yang sangat besar. Hal ini didukung oleh luas area wilayah Kabupaten Pangkajene dan Kepulauan dengan luas wilayah daratan $898,29 \mathrm{~km}^{2}$ dan wilayah laut $11.464,44 \mathrm{~km}^{2}$ (4 mil dari garis pantai) dengan jumlah 112 pulau (Pangkep dalam Angka, 2017). Untuk menjaga agar supaya rajungan tetap berkelanjutan maka perlu adanya pemanfaatan yang baik dan benar, diantaranya pengelolaan yang berbasis marine culture. Dalam pengelolaan ini diharapkan mendukung peningkatan produksi rajungan dan mampu mempertahankan keseimbangan sumberdaya rajungan (Ihsan, 2015).

Terkait dengan hal tersebut maka usaha mendukung peningkatan produksi rajungan, menjaga permintaan pasar dan mempertahankan potensi rajungan, maka dilakukan pengelolaan perikanan rajungan berbasis spasial dan marine culture dalam keramba jaring ditenggelamkan (KJT). Pengelolaan budidaya rajungan, diharapkan menjaga ketahanan pangan yang bersumber dari daging rajungan dan keberlanjutan sumberdaya rajungan.

Penelitian ini bertujuan untuk (1) mengkaji aspek fisika dan kimia oseanografi perairan Kecamatan Sigeri Kabupaten Pangkep, (2) mengetahui kesesuaian lokasi dan teknik budidaya rajungan dalam keramba jaring di tenggelamkan secara terpadu di perairan, serta (3) mengetahui strategi pengelolaan budidaya rajungan dalam keramba jaring di tenggelamkan secara terpadu di perairan.

\section{METODE PENELITIAN}

Penelitian ini dilaksanakan pada bulan Juli s/d Oktober 2018. Persiapan penelitian meliputi observasi lapangan dan penentuan lokasi penelitian. Alatalat yang digunakan dalam penelitian ini adalah alat untuk mengukur aspekaspek yang ada di parameter fisik, 
keperluan dokumentasi dalam penelitian, pengambilan data sosial masyarakat dan wisatawan serta bahan pustaka yang berkaitan dengan penelitian ini.

Jenis data yang dikumpulkan dalam penelitian ini dibagi menjadi lima kelompok dengan aspek-aspek yang diteliti sebagai diantaranya: biologi, fisika, kimia, masyarakat dan pengelola. Pengambilan kelima kelompok data ini menggunakan jenis data primer dan data sekunder.

Data primer yang dikumpulkan meliputi keadaan umum lokasi yakni bioekologi dan parameter oseanografi, isu-isu yang berkembang, kebijakan terhadap kawasan, persepsi, partisipasi dan harapan terhadap kawasan. Sedangkan untuk pengambilan data sekunder berasal dari studi pustaka, buku-buku laporan hasil penelitian sebelumnya, dan dari instansi terkait.

Dalam penelitian ini teknik analisis data yang digunakan adalah teknik analisis deskriptif, kualitatif, dan kuantitatif. Secara singkat seluruh analisis yang dilakukan diuraikan sebagai berikut:

\section{Analisis Parameter kualitas Air}

Pengamatan kualitas air selama penelitian meliputi aspek fisika dan kimia oseanografi perairan yang terkait dengan kesesuaian pemanfaatan kawasan pesisir untuk kegiatan budidaya rajungan dalam karamba jaring ditenggelamkan. Parameter kualitas air yang dianalisis antara lain, suhu, salinitas, $\mathrm{pH}, \mathrm{DO}$, dan tingkat kecerahan perairan.

\section{Analisis Kesesuaian Lokasi}

\section{Budidaya Rajungan}

Ihsan (2015) menjelaskan bahwa analisis kesesuaian untuk budidaya rajungan menggunakan sistem informasi geografis (SIG) dengan metode ArcView, yaitu sistem informasi spasial menggunakan komputer yang melibatkan perangkat keras (hardware), perangkat lunak (software), pemakaian data-data yang mempunyai fungsi pokok untuk menyimpan, memperbaharui, menganalisa dan menyajikan kembali semua bentuk informasi spasial.

\section{Analisis SWOT}

Analisis SWOT adalah analisis yang mengidentifikasi berbagai faktor internal dan eksternal secara sistematis untuk merumuskan strategis suatu kegiatan. Analisis ini didasarkan pada logika yang dapat memaksimalkan kekuatan (Stengths) dan peluang (Opportunities), namun secara bersama dapat meminimalkan kelemahan (Weaknesses) dan ancaman (Threats). Analisis ini membandingkan faktor eksternal yakni peluang dan ancaman dengan faktor internal yakni kekuatan dan kelemahan (Rangkuti, 2003).

\section{HASIL DAN PEMBAHASAN}

\section{Aspek Fisika dan Kimia \\ Oseanografi Perairan}

Hasil pengukuran suhu air pada 10 stasiun yang dipantau pada lokasi survey memiliki kisaran $29,9-33^{\circ} \mathrm{C}$ dan perubahan peningkatan suhu selama pengamatan tidak terlalu 
signifikan. BPBAP (2017) kisaran suhu yang layak adalah $28-32^{\circ} \mathrm{C}$. Suhu sangat mempengaruhi proses metabolisme pada semua organisme di dalam air, diantaranyan aktifitas fotosintesis dan respirasi, serta berpengaruh langsung terhadap meningkatnya nafsu organisme akuatik. Suhu sangat berpengaruh terhadap kelangsungan hidup dan perkembangan stadia pada rajungan, mulai dari telur, larva dan benih hingga berukuran dewasa. Suhu media pemeliharaan akan berpengaruh terhadap perkembangan larva setelah telur, hal ini di karenakan suhu dapat mempengaruhi laju penyerapan kuning telur yang merupakan sumber energi untuk proses metabolisme bagi larva.

Hasil pengukuran salinitas pada 10 stasiun pengamatan dengan menggunakan hand refraktometer berkisar antara 28-35 ppt. Salinitas menunjukan jumlah kadar garam yang terlarut di dalam perairan. Salinitas yang baik untuk budidaya rajungan berkisar antara 15-35 ppt (optimun 15-25 ppt). Namun rajungan masih bisa dipelihara pada salinitas rendah hingga 0,5 ppt dan pada salinitas tinggi hingga 50 ppt tetapi akan mengalami pertumbuhan yang lambat. Salinitas juga berpengaruh terhadap parameter kualitas air yang lain seperti kelarutan oksigen, tingkat toksisitas nitrit dan amonia (BPBAP, 2017).

Hasil pengukuran $\mathrm{pH}$ berada pada kisaran 7,8-8,2. Besarnya $\mathrm{pH}$ air yang optimal untuk kehidupan ikan dan rajungan adalah 6,5-8 (netral), karena pada kisaran tersebut yang optimal antara oksigen dan karbondioksida serta pada nilai tersebut, berbagai mikroorganisme yang merugikan akan sulit berkembang. Keputusan Menteri Negara Lingkungan Hidup No. 51 Tahun 2004 tentang baku mutu air laut untuk biota laut nilai $\mathrm{pH}$ tersebut masih dalam kisaran yang kelayakan hidup organisme akuatik yaitu 7-8,5. Hasil pengukuran DO pada 10 titik lokasi pengamatan ditemukan kisaran DO berada pada kisaran konsentrasi 5,22-6,62 ppm.

Menurut Keputusan Menteri Negara Lingkungan Hidup No. 51 Tahun 2004 tentang baku mutu air laut untuk biota laut kandungan oksigen terlarut yang ditetapkan yaitu $>5$ ppm. Oksigen merupakan salah satu gas yang terlarut dalam perairan. Kadar oksigen yang terlarut di perairan alami bervariasi, tergantung pada suhu, salinitas, turbulensi air, dan tekanan atmosfir. Semakin besar suhu dan ketinggian serta semakin kecil tekanan atmosfir, kadar oksigen terlarut semakin kecil (Jeffries dan Mills, 1996).

Hasil pengukuran kecerahan pada 10 titik lokasi pengamatan ditemukan kisaran kecerahan berada pada kisaran 30-90\%. Banyak sedikitnya sinar matahari yang menembus ke dalam perairan sangat bergantung dari kecerahan air. Semakin cerah perairan tersebut akan semakin dalam cahaya yang menembus ke dalam perairan. Penetrasi cahaya menjadi rendah ketika tingginya kandungan partikel tersuspensi di perairan dekat pantai, akibat aktivitas pasang surut dan juga 
tingkat kedalaman kisaran kecerahan yang baik untuk membudidayakan rajungan berkisar antara $>25 \mathrm{~cm}$ (BPBAP, 2017).

\section{Kesesuaian Lokasi budidaya rajungan dalam Karamba Jaring Ditenggelamkan}

Hasil analisis kesesuain perairan untuk kegiatan budidaya rajungan dalam karamba jaring ditenggelamkan (KJT) dengan menggunakan indikator suhu, salinitas, oksigen, $\mathrm{pH}$ dan kecerahan diperoleh 2 kriteria kesesuaian antara lain: sesuai luasnya $46.785,32$ ha dan tidak sesuai luasnya $1.152,4$ ha.

\section{Strategi Pengelolaan Budidaya}

\section{Rajungan}

\section{a. Kekuatan atau Strenght (S)}

Di wilayah pesisir Kabupaten Pangkep pekerjaan yang paling banyak dilakukan adalah nelayan, salah satu pekerjaan yang paling sering dikerjakan masyarakat nelayan adalah usaha perikanan rajungan baik sebagai nelayan penangkap, nelayan pengumpul, pengolah daging rajungan dan sebagai tenaga kerja setiap industri rumahan pengolahan daging rajungan dan lain-lain. Komoditi rajungan menjadi primadona bagi masyarakat, oleh karena itu maka motivasi nelayan dan pengusaha lokal dalam pemanfaatan perikanan tangkap rajungan sangat tinggi. Potensi sumberdaya perikanan tangkap rajungan masih cukup besar hal ini terlihat dari hasil tangkapan nelayan setiap harinya masih ada. Hasil analisis potensi lestari diperoleh sebesar 1.084.066 ton/tahun.

\section{b. Kelemahan atau Weaknesses $(W)$}

Pengelolaan budidaya rajungan (P. pelagicus) terkait dengan beberapa stakeholder diantaranya unsur pemerintah, pengusaha dan lembaga sosial kemasyarakatan. Selama ini masih terjadi belum terpadaunya atau terkoordinasi di antara komponen stakeholder tersebut serta inplementasi antar stakeholder kurang bersinergi yang mengakibatkan peran-peran yang semestinya dilakukan bersama-sama berjalan dengan secara sendiri-sendiri dan akhirnya terjadi tumpang tindih.

\section{c. Peluang atau Opportunities $(O)$}

Permintaan pasar perikanan tangkap rajungan sangat tinggi, hal ini terlihat dari meningkatnya permintaan pasar dari berbagai negara. Kementerian Kelautan dan Perikanan, (2008) menjelaskan bahwa daging rajungan jenis blue swimming crab tetap pemegang pangsa pasar terbesar (41\%). Pasar rajungan tumbuh sekitar $15 \%$ pertahun dan diperkirakan akan menjadi dua kali lipat dalam lima tahun mendatang. Industri rumah tangga pengolahan daging rajungan berkembang dengan pesat. Beberapa tahun terakhir di setiap Kecamatan kecil dan pulau-pulau kecil terdapat industri rumah tangga pengolah daging rajungan. Industri-industri ini setiap harinya mengolah rajungan dengan produksi hasil olahan daging antara $100-200 \mathrm{~kg}$.

\section{d. Ancaman atau Trearts (T)}

Penangkapan rajungan pada fase zoea 4 , megalopa dan rajungan muda 
sangat tinggi, terutama untuk alat tangkap mini trawl, hasil pengamatan menunjukan bahwa setiap trip jumlah rajungan muda yang tertangkap dengan alat tangkap mini trawl sangat banyak. Penyebabnya adalah karena alat tangkap mini trawl yang digunakan nelayan tidak selektif dan merusak lingkungan. Demikian juga sebagian rajungan yang tertangkap adalah bertelur atau telah matang gonad. Upaya penangkapan meningkat setiap tahun, baik dari segi jumlah alat tangkap maupun frekwensi waktu penangkapan rajungan yang dilakukan oleh nelayan pagi, siang, sore dan malam hari. Hasil tangkapan rajungan betina lebih besar daripada jantan dan nelayan tidak pernah berhenti melakukan penangkapan. Beberapa alat tangkap yang dioperasikan oleh nelayan secara tidak langsung mematikan secara massal rajungan pada fase megapola karena terjebak pada alat tangkap tersebut. Target produksi penangkapan tinggi yang menyebabkan nelayan selalu berusaha untuk memenuhi target tersebut tanpa pernah memahami daya dukung potensi rajungan yang tersedia di alam.

\section{KESIMPULAN}

Berdasarkan analisis dan pembahasan maka disimpulkan sebagai berikut :

1. Hasil analisis kesesuaian perairan untuk kegiatan budidaya rajungan dalam karamba jaring ditenggelamkan (KJT) dengan menggunakan indikator suhu, salinitas, oksigen, $\mathrm{pH}$ dan kecerahan diperoleh dua kriteria kesesuaian yaitu sesai dan tidak sesuai. Dari hasil analisis kesesuain lahan budidaya rajungan diperoleh dua kriteria kesesuaian lahan budidaya yaitu 46.785,32 ha dikategorikan sesuai dan 1.152,4 ha dikategorikan tidak sesuai.

2. Strategi pengelolaan yang dapat diterapkan untuk mewujudkan pengelolaan budidaya rajungan secara terpadu, antara lain : a) Pengeloaan budidaya rajungan secara terpadu; b) Pengembangan dan sosialisasi budidaya rajungan; c) Penegakan hukum terkait perusakan ekosistem pesisir d) Pelarangan penangkapan rajungan yang bertelur; e) Pengembangan dan pemberian modal usaha; f) Pengadaan bibit untuk kebutuhan budidaya rajungan.

\section{SARAN}

Untuk mendukung usaha peningkatan produksi rajungan, menjaga permintaan pasar dan mempertahankan potensi rajungan, maka perlu dilakukan pengelolaan perikanan rajungan berbasis spasial dan marine culture dalam karamba jaring ditenggelamkan (KJT). Pengelolaan budidaya rajungan ini diharapkan dapat menjaga ketahanan pangan yang bersumber dari daging rajungan dan keberlanjutan sumberdaya rajungan.

\section{UCAPAN TERIMA KASIH}

Penulis mengucapkan terima kasih kepada semua pihak yang telah memberikan dorongan dan bantuan 
kepada penulis yang tak dapat penulis sebutkan satu persatu dan para reviewer yang telah banyak memberikan masukan dan komentar dalam penulisan ini.

\section{DAFTAR PUSTAKA}

BPBAP Takalar. 2017. Panduan Teknis Budidaya Rajungan Di Tambak. Kementerian Kelautan dan Perikanan, Direktorat Jenderal Perikanan Budidaya.

Fauzi A. dan S. Anna. 2004. Evaluasi Status Keberlanjutan Pembangunan Perikanan. Aplikasi pendekatan RAPFISH. Jurusan sosek fakultas perikanan dan kelautan FPIK. IPB. Bogor.

Ihsan, 2015. Pemanfaatan Sumberdaya Rajungan (Portunus pelagicus) Secara Berkelanjutan di Perairan Kabupaten Pangkajene

Kepulauan. Makassar.

—,. 2015. Pemanfaatan Rajungan Berbasis Spasial di Perairan Kabupaten Pangkep. Makassar

$\begin{array}{crr}\text {, 2017. } & \text { Model Integrasi } \\ \text { Pengelolaan } & \text { Sumberdaya }\end{array}$

Rajungan (Portunus Pelagicus) Berkelanjutan berbasis spasial di Kabupaten Pangkep. Makassar.

Rangkuti F, 2003. Analisis SWOT Teknik Membedah Kasus Bisnis. Reorientasi Konsep Perencanaan Strategis Unutk Menghadapi Abad 21. PT. Gramedia Pustaka Utama. Jakarta.

Keputusan Menteri Jakarta.Negara Lingkungan Hidup Nomor 51 Tahun 2004 Tentang Baku Mutu Air Laut (Biota Laut).

Jeffries, M., and D. Mills. 1996. Freshwater Ecology, Principles and Aplication . john Wiley and Sons. Chicester UK.

Peraturan Menteri Kelautan Dan Perikanan Republik Indonesia Nomor 2/PERMEN-KP/2015 Tentang Larangan Penggunaan Alat Penangkapan Ikan Pukat Hela (Trawls) Dan Pukat Tarik (Seine Nets) di Wilayah Pengelolaan Perikanan Negara Republik Indonesia. Berita Negara Republik Indonesia Tahun 2015 Nomor 31. 